\title{
Tadeusz Budrewicz
}

Instytut Filologii Polskiej,

Uniwersytet Pedagogiczny im. Komisji Edukacji Narodowej w Krakowie

\section{Obchody rocznicy Chopina w roku 1910 a integracja narodowa. Chopin a kultura pamięci}

Uroczystości i obchody jako przejawy kultury pamięci Polaków w okresie zaborów mają już obfitą literaturę przedmiotu. Na jej podstawie można oprzeć opis konkretnego święta (lokalnego czy narodowego) i ulokować je na mapie zjawisk pokrewnych, aby przeprowadzić interpretację faktu uwzględniającą zarówno jego specyfikę, jak i wielorakie konteksty czy determinanty wpisujące go w szerszy nurt ideoestetyczny'. Obok studiów źródłowych, porządkujących i systematyzujących, pojawiają się nowe, nieraz bardzo odkrywcze propozycje metodologiczne, które skłaniają ku nieeksplorowanym dotąd kierunkom interpretowania znanych już

1 Wymienić można następujące opracowania tego zagadnienia: Obchody rocznicowe na prowincji zaboru austriackiego [Galos 1993], Gotab i orzet. Obchody rocznic kościuszkowskich w latach 1894 i 1917 [Micińska 1997], Walczyć nauką za sprawę Ojczyzny. Zjazdy ponadzaborowe polskich środowisk naukowych i zawodowych jako czynnik integracji narodowej (1869-1914) [Cabaj 2007], Narodowe widowiska kulturowe. Uroczystości żałobne i rocznicowe $w$ Wielkopolsce (1815-1914) [Piotrowska 2011], Setna rocznica urodzin Józefa Ignacego Kraszewskiego $w$ prasie warszawskiej [Stępnik 2012], Uroczystości żatobne jako narzędzie legitymizacji i delegitymizacji wtadzy [Napiórkowski 2013], Upominki od narodu. Jubileusze, obchody, rocznice pisarzy [Budrewicz, Bukowski, Stachura-Lupa, red. 2019]. 
materiałów. Perspektywy badawcze kultury pamięci mogą ożywić i przeorientować refleksje nad XIX-wiecznym kultem wybitnych postaci personifikujących losy narodu [por. Minta-Tworzowska 2013; Jankowska 2014; Marzec 2015; Tabaszewska 2016; Piotrowska 2018, 2019]. Polski wiek XIX można przedstawić tak:

Powszechny system wartości kształtowały przede wszystkim wielkie jubileusze, do których można zaliczyć na przykład: hucznie obchodzone pięćdziesięciolecie pracy twórczej Józefa Ignacego Kraszewskiego w 1879 roku, czterechsetlecie urodzin Mikołaja Kopernika w 1873 roku, dwusetlecie wiedeńskiej wiktorii w 1883 roku, setną rocznicę uchwalenia Konstytucji 3 Maja w 1891 roku, stulecie powstania kościuszkowskiego w 1894 roku, setną rocznicę urodzin Adama Mickiewicza w 1898 oraz urodzin Juliusza Słowackiego w 1909 roku, jubileusz pracy Henryka Sienkiewicza w 1900 roku, ćwierćwiecze pracy Marii Konopnickiej w 1902 roku, czterdziestolecie pracy literackiej Elizy Orzeszkowej w 1907, uroczystości grunwaldzkie w 1910 roku. [Gabryś-Sławińska 2015: 378-379]

Powyższa lista jest jedną z wielu możliwych. Każdy z nas ma nieco odmienne upodobania i wedle nich hierarchizuje ważność składników tworzących wiedzę historyczną. Samego znaczenia rocznic nikt nie podważa, choć bywają różnice zdań co do ich wyborów². W przytoczonym cytacie widać znamienną przewagę liczbową ludzi pióra bądź nauki nad herosami wsławionymi działaniami oręża i równie charakterystyczną przewagę czynu zbrojnego zbiorowości nad indywidualnym przykładem bitewnego bohaterstwa. Takie było symboliczne oblicze wieku XIx - polski Król Duch wcielił się w pisarzy, których głosów słuchały tłumy. Można to ująć prościej: jako relację między geniuszem a masami. Jakkolwiek

2 Galicja „urządzała rocznice narodowe. Czasami popełniała w wyborze rocznic błędy. Z tego punktu widzenia wychodząc, uznawaliśmy za stosowne urządzać obchody rocznicy Trzeciego Maja, gdyż żyć w nas winna dążność demokratyzacji narodu dla uzyskania przymnożenia jego siły, co stanowiło treść ideową Konstytucji Trzeciego Maja. Winniśmy obchodzić rocznice naszych powstań, gdyż walka orężna z Rosją o nasze wyzwolenie nie powinna zanikać z programu narodowego" [Studnicki 1915]. 
byśmy rzecz nazywali, warto podkreślić, że na tej liście ważnych rocznic nie ma uroczystości poświęconych pamięci muzyków ani malarzy. Osiągnięcia sztuki polskiej w wieku XIx były większe niż kiedykolwiek wcześniej, lecz nie wytrzymały porównania z pozycją ludzi pióra. Malarstwo i muzyka poważna wciąż jeszcze miały elitarny krąg odbiorców. Niewątpliwie Fryderyk Chopin i Artur Grottger owładnęli polską duszą zbiorową bardzo głęboko, jednak nawet $w$ tym przypadku drogą do uznania ich pozycji było zastosowanie nobilitującego określenia "poezja” (Chopin: „poeta muzyczny” [Rozmaitości 1881], „poeta tonów” [Żukowski 1910: 7], „czwarty wielki poeta Polski podzielonej” [Tarnowski 1892: 6]; Grottger: „poeta wielkiego natchnienia” [Tarnowski 1892: 53], "Grottger to nie malarz, ale poeta, który zamiast słowem przemawia rysunkiem” [Rogosz 1876: 102]) 3. W obchodach narodowych muzyka długo pełniła funkcję dopełniającą, ilustracyjną, choć dość wcześnie sformulowano pogląd o jej ideowo-wychowawczej roli w takich uroczystościach:

Celem ich nierównie może ważniejszym i podnioślejszym jest krzewienie miłości ojczyzny i rzeczy swojskich. [...] Jeżeli więc wieczory mają osiągnąć, obok celu czci i pamiątki, cel dodatni dla społeczeństwa współczesnego i młodej generacji, powinny we wszystkich kierunkach krzewić miłość ojczyzny i rzeczy swojskich, a więc i w kierunku muzykalnym. Utwory więc na obchodach wykonywane powinny być wyłącznie dziełami kompozytorów polskich. [...] boć w końcu zapomni podrastająca generacja, że naród nasz posiada rodzimą, swojską muzykę. [Wszelaczyński 1891: 1-2]

„Krzewienie miłości ojczyzny i rzeczy swojskich”, czyli formowanie i utrwalanie tożsamości narodowej, wysuwało się na plan pierwszy w obchodach i uroczystościach. Integrowało naród podzielony

3 Drobny przykład prymatu literatury nad muzyką: pięćdziesiąta rocznica urodzin Fryderyka Chopina nie została odnotowana w „Tygodniku Ilustrowanym”. Numery chronologicznie związane z datą przyjścia na świat kompozytora (1860, $\mathrm{nr}$ 22-23) poświęcono Stanisławowi Jachowiczowi i Janowi Czeczotowi. W przytaczanych $\mathrm{w}$ artykule cytatach $\mathrm{z}$ tekstów źródłowych oraz $\mathrm{w}$ tytułach tychże tekstów zmodernizowano w podstawowym zakresie ortografię. 
na trzy dzielnice zaborcze, dodatkowo rozproszony po świecie wskutek emigracji zarobkowej i politycznej. Wśród historyków panuje zgodna opinia, iż w drugiej połowie wieku XIX rozebrane dzielnice dawnej Polski podlegały sprzecznym tendencjom: procesowi dezintegracji pod względem gospodarczym, a zarazem integracji pod względem kulturowym [Galos 1976: 9] $]^{4}$. Integracja to głównie codzienna, daleka od form spektakularnych, praca inteligencji obejmująca: szkolnictwo, ruch prasowy, księgarsko-wydawniczy, biblioteczny. Za rzadko się mówi o literacko-publicystycznych obrazach rzeczywistości z jednego zaboru, które prezentowano w innych dzielnicach, o tej formie „wymiany usług” ideowo-kulturalnych, o rozlicznych i rozmaitych formach międzyzaborowych kontaktów, wypełnionych nieraz treściami praktycznymi i w sposób niezauważalny podtrzymujących poczucie więzi $\mathrm{w}$ narodowej rodzinies. Uwagę badawczą częściej skupiamy na integracji, którą realizowano poprzez formy parateatralne, widowiskowe - obchody i zjazdy. Nic zresztą dziwnego, skoro relacje o tych uroczystościach i wytwarzane na ich potrzeby artefakty (pamiątki, wydawnictwa okolicznościowe, fotografie etc.) szerokimi falami zalewały masy i na długo stanowiły żywy składnik kultury. Obchody rocznicowe i zjazdy o charakterze ponadlokalnym, międzyzaborowym upowszechniły się w drugiej połowie wieku, a kulminację osiągnęły w dziesięcioleciu 1905-1914, czyli bezpośrednio przed Wielką Wojną, która zakończyła okres rozbicia kraju [Cabaj 2007: 326-327]. Stanowiły dwa modele uczestniczenia w narodowej kulturze - obchody były nakierowane na wczoraj, na przeszłość i pamięć, koncentrowały tysiące uczestników reprezentujących różne grupy społeczne powiązane ideą narodu; zjazdy miały charakter branżowy, elitarny, działania ich uczestników były nakierowane na wizję przyszłego świata, budowanie jutra lepszego

4 W dalszej części publikacji autor formułuje sąd o roli muzyki - w znamienny sposób bardzo ogólnikowy: „Integracyjna rola muzyki nie ulega wątpliwości, choć zawsze pozostanie pytanie, w jakim stopniu chodziło o ogólnoludzkie wartości artystyczne, a w jakim o narodowy charakter utworów" [Galos 1976: 32 ].

5 Niektóre aspekty problemu (odpowiedzi redakcji jako dokumenty geograficznego zasięgu periodyków, przemieszczanie się pisarzy i dziennikarzy oraz ich współpraca z pisarzami z innych zaborów) wskazywałem w swoich artykułach [Budrewicz 2019a; 2020]. 
niż dziś (prospektywny, programowy charakter miały uchwały zjazdów). Oczywiście możliwe były kompilacje tych modeli - zjazdy połączone z upamiętnianiem osoby, którą obierano patronem ideowym (np. Pierwszy Zjazd Historyczny Polski im. Jana Długosza odbyty w Krakowie w czterechsetną rocznicę śmierci, 1880; Zjazd Historyczno-Literacki im. Jana Kochanowskiego, 1884). Takim też przykładem modelu synkretycznego były obchody setnej ${ }^{6}$ rocznicy urodzin Chopina w 1910 roku, które połączono z Pierwszym Zjazdem Muzyków Polskich.

\section{Różne formy kultu}

Popularność Chopina jako kompozytora w wieku XIX wciąż rosła. Kult muzyka, a więc forma społecznego uznania jego rangi i wpisania go na listę narodowej dumy - jako ważnego elementu tożsamości - upowszechniał się wolniej. Znane są perypetie z ustaleniem dokładnej daty jego narodzin, choć i one nie tłumaczą milczenia polskiej prasy w pięćdziesiątą rocznicę urodzin kompozytora. Pamiętano o dacie śmierci, długo nie pamiętano o urodzinach. $\mathrm{Z}$ inicjatywą uroczystego obchodzenia urodzin wystąpiło Towarzystwo Muzyczne w Warszawie w roku 1873. „Na dzień podobny wielki muzyk czekał u nas długo, więc tym świetniejsza winna być pierwsza uroczystość" $[(\mathrm{m}) \text { 1873] }]^{7}$. Z tej okazji urządzono specjalny wieczór chopinowski, na którym uwieńczono laurem popiersie muzyka, a wyrzuty sumienia rodaków przybrały postać westchnienia: „A myśmy o nim tak długo zapominali!” [-Q-1873: 2] $]^{8}$. Zgoła inaczej było z opisem zgonu, który prędko stał się rozrzewniającym motywem uwznioślającej śmierci romantycznego artysty,

6 Przeciw upowszechniającym się pod koniec XIX wieku formom „stuletnia”, „5o-letnia” rocznica jako „dziwolągom językowym” wysuwano prosty argument poprawnościowy, wart przypomnienia: „Nikt przecie nie powie: rocznica jednoroczna lub dwuletnia, tylko pierwsza, druga...” [Odpowiedzi redakcji 1904].

7 Wieczorki rocznicowe gromadziły liczną publiczność, nawet do 300 osób [„Kurier Warszawski” 1874].

8 Wieczór urządzono w „64-tą rocznicę urodzin”, zatem wtedy jeszcze jako datę narodzin kompozytora przyjmowano 1 marca 1809 roku, choć już kwestionowano to ustalenie. Biografowie stanowczo podtrzymywali wersję pierwotną, odmawiając racji innym [por. Karasowski 1877]. Pomyłkowe daty były też umieszczane na pomnikach Chopina [por. Rzeczy bieżace 1879, $\mathrm{nr} 23$ ]. 
wniebowstąpienia wprost z łoża boleści („Tak chrześcijańska dusza Szopena wraz z hymnem świętym uleciała do nieba" [Dołęga $\left.{ }_{1855}\right]^{9}$ ). Kult muzyka potęgowal się, czego niekwestionowanym dowodem są dzieła malarskie i rzeźbiarskie, które były przedmiotem licznych publikacji w prasie, zapewne też wielokrotnie liczniejszych rozmów prywatnych, i które plastycznie utrwalały jego wizerunek $w$ zbiorowej pamięci. Podejmowano akcje zbierania funduszy na postawienie pomnika Chopina (najpierw planowano budowę „pomnika filarowego” w kościele św. Krzyża [Rzeczy bieżące 1879a, nr 9: 1]); tym samym wielu anonimowych ofiarodawców przyczyniało się do pogłębiania kultu. Odsłonięcie marmurowego posągu dłuta Leonarda Marconiego, połączone $\mathrm{z}$ wmurowaniem $\mathrm{w}$ kolumnę puszki zawierającej serce zmarłego, było aktem uroczystym, „symbolicznym utrwaleniem w pamięci współczesnych i potomnych niewygasłej aureoli poezji, która otaczała nazwisko Szopena w ciągu całego życia i po śmierci artysty”. Samo miejsce uznano za stosowne, gdyż „świątynię wzniesiono pod znakiem cierpienia" [-B- 1880; Kronika 1880, nr 6 i 11; Pamięci Fryderyka Szopena 1880$]^{10}$. Tym samym Chopin wszedl do panteonu narodowego ze znakami męczeństwa jako człowiek oderwany od rodzinnej ziemi, cierpiący z tego powodu, a myślą i sercem wciąż z nią związany. Rytualizacja form pamięci, wymagająca ustalenia kalendarza rocznic, zaczyna się 35 lat po śmierci kompozytora. W roku 1884 zgloszono postulat corocznego obchodzenia Dnia Chopina [zob. Dzień Szopena 1884]. Pomniki w publicznej przestrzeni otwartej, których siła aktywizowania zbiorowej pamięci przewyższa artefakty ulokowane w obiektach zamkniętych, pojawiły się dość późno. Nie zawsze ich odsłanianie było publicznym świętem narodowym, wskutek czego do dziś występują przypadki dezinformacji, np. dotyczące pomnika na krakowskich Plantach. Popiersie ulokowane na cokole wykonał Władysław Marcinkowski. Zakupił je znany mecenas sztuki Konstanty Wołodkowicz, który następnie ofiarował

9 Obok aspektu etycznego (ideały chrześcijańskie, wartość przyjaźni) opisy podkreślały jakości estetyczne aktu konania: „Bądź co bądź, piękną była ta śmierć” [Kleczyński 1880].

10 Upamiętnienie artysty uważano za moralny obowiązek rodaków („Tak więc Warszawa postawiła nareszcie kamień grobowy największemu z artystów swej ziemi” [Kronika tygodniowa 1880]). 
je miastu, deklarując pokrycie kosztów ustawienia pomnika. Trzeba było ponad roku, by Rada Miasta wyraziła na to zgodę, korygując nieco planowaną lokalizację obiektu. Odsłonięciu pomnika nie towarzyszyły żadne uroczystości - wykonano robotę, ustawiono pomnik, w dodatku opatrzony fałszywą datą urodzin, co zmusiło Władysława Żeleńskiego do interwencji prasowej. Gdyby nie ona, krakowianie długo by nie wiedzieli, że ich miasto wyprzedziło inne pod względem okazywania przejawów kultu kompozytora ${ }^{11}$. Nic się nie mówiło o postawionym w krakowskim parku Jordana popiersiu autorstwa Alfreda Dauna [Świejkowski 1905: 54]. Niepokaźny pomnik na Plantach stał się jednak katalizatorem uczuć narodowych przybierających formy manifestacji, miejscem wyrażania sprzeciwu młodej generacji wobec demonstrowanego lojalizmu c.k. Austrii; pod pomnikiem gromadzili się przedstawiciele narastającej idei buntu młodzieży, która się odwoływała do romantycznego rozumienia narodowości [por. Grabiec 1899] ${ }^{12}$. W końcu wieku XIX na ziemiach polskich Chopin przestawał być pamiętany jako wirtuoz fortepianu; był zaś kompozytorem, który rodzimą polską nutę życia ludu i szlachty (mazurki, polonezy) wprowadził do kultury światowej; który natchnienie czerpał z duszy polskiego ludu, a czynił to tak doskonale, że ów lud tańczył do wtóru jego muzyki [Halszka z Zaskala 1910] ${ }^{13}$.

11 Informację o projekcie Konstantego Wołodkowicza podał Władysław Łuszczkiewicz [189o; zob. też Teatr i sztuka 189o; Kronika miejscowa i zamiejscowa 189o; Kronika 1891; Nowa ozdoba Plantacji... 1891]. List Władysława Żeleńskiego zamieścił w czasopiśmie „Czas” [(List W. Żeleńskiego) 1891]. Krytyka władz miasta za zlekceważenie sprawy „pomniczka” tak miniaturowego, ,że przez powiększające szkła trzeba go oglądać”, ukazała się w czasopiśmie „Diabel” [Uwagi śledziennika 1891].

12 Chodzi o krytykę władz za zlekceważenie pięćdziesiątej rocznicy śmierci Chopina przy jednoczesnej pamięci o jubileuszu rosyjskiego poety Aleksandra Puszkina. W świetle relacji z „Czasu” i „Głosu Narodu” te zastrzeżenia trzeba traktować jako zaostrzony wyraz stanowiska opozycji wobec władz miasta. Szczególnego znaczenia nabrała manifestacja młodzieży pod pomnikiem w 1910 roku, kiedy uroczyste obchody rocznicy urodzin Chopina przesunięto w czasie, gdyż akurat do Krakowa przybył minister dla Galicji Władysław Dulęba [por. Manifestacja pod pomnikiem Chopina 1910; Manifestacja pod pomnikiem Chopina w Krakowie 1910; Młodzież akademicka - Szopenowi 1910].

13 Na zakończenie uroczystości jubileuszowych we Lwowie odbył się specjalny „wielki koncert ludowy” z udziałem Ignacego Paderewskiego; w finale połączone orkiestry i chóry włościańskie wykonały pieśni narodowe [zob. Wasz. 1910]. Obecność reprezentantów ludu na podobnych uroczystościach była stałym elementem sprawozdań prasowych. 
Odsłonięcie pomnika w Żelazowej Woli 14 października 1894 roku, w którym wzięło udział ok. 2500 ludzi, było już świętem narodowym, utrwalonym w licznych opisach prasowych we wszystkich zaborach i za oceanem. Fundusze na realizację przedsięwzięcia zdobyto na koncertach. Aby uniemożliwić tłumne świętowanie, władze rosyjskie zwlekały z wydaniem pozwolenia na uroczysty obchód aż do 9 października [Urbanus 1894]. Fotografie pomnika oraz stojącego przy nim chłopa Antoniego Krysiaka (ostatniego strażnika żywej pamięci o pobycie Fryderyka w Żelazowej Woli) obiegły kraj [Poliński 1894; Święto Chopina 1894; Uroczystości Chopina 1894; Uroczystość Chopina 1894; Uroczystość w Żelazowej Woli 1894]. Czterdziesta piąta rocznica śmierci nie stwarzała okazji do tak podniosłego świętowania, w tym jednak wypadku warto było się trudzić, by inicjatywę zapoczątkowaną jeszcze w roku 1891 doprowadzić do skutku - rok 1894 to rok narodowych obchodów powstania Tadeusza Kościuszki, Wystawy Krajowej we Lwowie, rok bilansu narodu w smutne stulecie niewoli. Odsłonięcie pomnika Chopina wpisywało się w działania mające pogłębić integrację narodu.

Obchody Chopinowskie na przełomie wieku XIX i xx przybrały formy uroczyste, świąteczne, w części nawet religijne ${ }^{14}$. Wkomponowywały się w ówczesny ciąg rocznic narodowych ${ }^{15}$, stawiający tamę tendencjom dezintegracyjnym. Jakby przedłużeniem obchodów setnej rocznicy urodzin Mickiewicza, która przyniosła Warszawie pomnik poety (choć okupiony wstydliwym aktem hołdu złożonego carowi [Budrewicz 2004]), były uroczystości pięćdziesiątej rocznicy śmierci Chopina w 1899 roku. Poznawczy i artystyczny plon tych obchodów był imponujący, gdyż zaowocował wieloma numerami specjalnymi czasopism. Zarysowano w nich

14 Częścią „aktu religijnego” było składanie wieńców [„Kurier Warszawski” 1894]. Kulminacyjnym momentem uroczystych koncertów rocznicowych było wieńczenie laurem popiersia muzyka w salach koncertowych i na placach publicznych [Czapelski 1899]; utarł się też zwyczaj, że podczas wykonywania Marsza żałobnego publiczność wstawała [Hołd Chopinowi 1899; Z Warszawy 1899]; pamiątki po Chopinie nazywano „relikwiami” [„Echo Muzyczne, Teatralne i Artystyczne” 1894].

$15 \mathrm{Za}$ niestosowne, biorąc pod uwagę policyjne trudności stawiane przez władze pruskie i rosyjskie podczas prób urządzania obchodów, uważam określenie „szał rocznicowy", choćby było użyte bez intencji pejoratywnych [Bończa-Tomaszewski 2006: 144; Piotrowska 2011: 15-16]. 
biografię artysty, pogłębiając ją od strony faktograficznej z uwzględnieniem przeoczonych dotąd źródeł; dokonano interpretacji muzykologicznej utworów Chopina, skutkującej analizą kontekstów kulturowo-filozoficznych epoki; zarejestrowano aktualny stan posiadania pamiątek po muzyku oraz obiektów i form jego kultu, które dodatkowo utrwalono w formie fotografii; przygotowano wiele koncertów wzbogaconych prelekcjami oraz deklamacjami utworów literackich, a także pomysłowymi i pogłębiającymi sferę przeżyć efektami scenograficznymi; nastąpił dodatkowo prawdziwy wysyp wierszy o Chopinie, impresji lub tzw. przekładów konkretnych utworów muzycznych na język poezji. „Zdawałoby się, że społeczność nasza ochłonęła dopiero z żalu po stracie ukochanego mistrza i że rozmyśla nad sposobami uczczenia go jakąś trwałą pamiątką i dziwi się sama, że dotąd tego nie uczyniła” [Żeleński 1899]. Wyjątkową wartość mają numery 41 i 42 „Echa Muzycznego, Teatralnego i Artystycznego" z roku 1899. Już wtedy podjęto zamysł sprowadzenia do kraju zwłok Chopina (w Londynie zawiązał się w tym celu komitet, co symbolicznie zwracało uwagę na jedność narodu mimo zaborów i emigracji, podobnie jak relacje z uroczystości obchodzonych w Paryżu [K.R. 1899; Na cześć Chopina 1899 ] ${ }^{16}$ ). Imponującą pracę wykonały redakcje tzw. ilustracji: „Biesiady Literackiej”, „Bluszczu”, „Tygodnika Ilustrowanego”, „Wędrowca”. Ukazały się nawet numery specjalne poszczególnych dzienników, w których opublikowano materiały umożliwiające pogłębioną pracę nad tematem: Chopin w muzyce polskiej i światowej. Tu warto wspomnieć o „Kurierze Warszawskim” (1899, nr 287) i „Słowie” (1899, nr 239). Ta rocznica przyczyniła się też do zdynamizowania prac organizacyjnych polskiego ruchu muzycznego (powstanie

16 Z inicjatywą sprowadzenia zwłok Chopina do kraju wystąpili studenci lwowscy. W lutym 1899 roku powołano komitet, który jednak wzią się do dzieła niedyplomatycznie, narażając się na protest Władysława Mickiewicza, i zmienił zakres działalności, łącząc się z krakowskim komitetem sprowadzenia zwłok Juliusza Słowackiego [„Gazeta Lwowska” 1899; Niewiadomski 1899; „Słowo Polskie” 1899]. Ciekawy przykład integracji między emigracją a krajem oraz między zaborami stanowi sprawa „trwałego wieńca” przysłanego „od kolonii polskiej z Londynu” do Krakowa i złożonego pod pomnikiem na Plantach; wieniec ten wyekspediowano następnie do Warszawy, aby zdobił pomnik muzyka w kościele pw. św. Krzyża [zob. Z Krakowa. 16/10 1899]. 
sekcji Chopina w warszawskim Towarzystwie Muzycznym obok już istniejącej sekcji im. Stanisława Moniuszki), co z kolei pozytywnie wpłynęło na realizację ważnych dla dziedzictwa kulturowego narodu inicjatyw utworzenia Muzeum Chopina oraz upamiętnienia muzyka przez wystawienie monumentalnego pomnika w Warszawie (stały temat warszawskiej prasy w pierwszej dekadzie $\mathrm{xx}$ wieku). Pięćdziesiąta rocznica zgonu przyniosła też wzrost uczuć patriotycznych, przejawiający się np. w apelach o dopilnowanie, by pomnik artysty w Paryżu zaświadczał o jego poczuciu polskości [Lector 1898; Sarmaticus 1898].

\section{Obchody narodowe w roku 1910}

Setna rocznica urodzin obchodzona w roku 1910 była narodowym świętem Polaków i aktem narodowej jedności. Podobne uroczystości (jubileusze, odsłanianie pomników) upamiętniające Johanna Sebastiana Bacha, Georga Friedricha Händla, Ludwiga van Beethovena czy Roberta Schumanna podnosily uniwersalne wartości ich artyzmu [Kronika 1880, nr 6 i 11; St. 1885]. Tym razem kraj urodzin mistrza tonów upominał się o jego miejsce na kulturalnej i politycznej mapie Europy. W jubileuszowym roku doradzano narodowi, aby w muzyce Chopina słyszał mistyczne echa idei polskości. Marsz pogrzebowy miał być utworem, który oddaje ból „własną śmierć opłakującego narodu” [ Tobiczyk-Stefanowska, oprac. 1909: 108]. W polonezach mistrz tworzył wizję przeszłości kraju ojczystego, czasu, „kiedy to granice Polski tworzył z jednej strony Bałtyk, z drugiej zaś Morze Czarne", kiedy było słychać szum husarskich skrzydel, sejmikowe trzaskanie w karabele i szelest zarzucanych wylotów kontusza, a później „brzęk kajdan zesłańców, przykutych do taczek w kopalniach sybirskich" [Tobiczyk-Stefanowska, oprac. 1909: 30-31]. Obchodom Roku Chopinowskiego towarzyszyło przekonanie, że „Główną cechę muzyki Chopina stanowi wybitna odrębność narodowa [...] wyraz polskiego ducha, polskich uczuć i poezji”, a jej tonem dominującym jest ,tęsknota i żal” [Tobiczyk-Stefanowska, oprac. 1909: 31-32].

Rocznica wypadła jakby na przecięciu ideowych nurtów: kultu jednostek wybitnych i wspólnoty narodowej. Z jednej strony było 
przekonanie, iż „ciekawość powszechna ześrodkowywa się coraz bardziej wokół osobistości genialnych i wybitnych z przeszłości danego narodu" [Z. 1899]. Z drugiej - słowa Ignacego Paderewskiego wyrzeczone w chwili narodowego skupienia, gdy wszyscy na nie czekali: „Człowiek, choćby największy, ani nad narodem, ani poza narodem być nie może” [Paderewski 1910]. A były to słowa człowieka, który niedawno odmówił wystąpienia na koncercie w amerykańskiej ambasadzie, aby się tam nie spotkać z cesarzem niemieckim [Paderewski a Roosevelt 1910], i który ofiarował rodakom symbol narodowej dumy - pomnik Władysława Jagiełly. Te słowa zapadały w pamięć jako preambuła do nowoczesnego kodeksu etyki narodowej. Prymat idei narodowej podczas obchodu Chopinowskiego był widoczny, a nawet oficjalnie zadekretowany uchwałami komitetów organizacyjnych, by nie przyćmił rocznicy bitwy pod Grunwaldem. Organizacja Roku Chopina była podporządkowana doświadczeniom roku 1909, kiedy obchodzono stulecie urodzin Juliusza Słowackiego [Hahn 1916] (już od 1908 roku łączono obchody urodzin Słowackiego i Chopina w jedną akcję integrującą naród [Dobrzycki 1908: 238] ${ }^{17}$ ). To ono zaktywizowało dyskusję o sprowadzeniu zwłok muzyka do kraju ${ }^{18}$. Przede wszystkim jednak przykre doświadczenia $\mathrm{z}$ władzami policyjno-administracyjnymi ${ }^{19}$ Prus i Rosji przesądziły, że centralne uroczystości

17 Dowodem łączenia tych twórców jest uchwała komitetu poznańskiego: „Słowacki - Szopen: obcy sobie za życia, a przecież bliscy twórczym swym duchem [...] twórczość Juliusza i Fryderyka z tak pokrewnych wyrosła pierwiastków, wyrosła $\mathrm{z}$ duszy wielkich tułaczów-romantyków $[\ldots]$ których serce stale przepojone było bezbrzeżną za krajem tęsknotą" [W setną rocznicę... 1910].

$18 \mathrm{~W}$ dyskusjach powtarzano słowo „Wawel”. Oryginalne stanowisko zajął Wacław Gąsiorowski - twierdził, że „testament twórczy” muzyka wyznaczył mu miejsce wiecznego spoczynku w ,wiosce, w której ujrzał światło dzienne”, w formie kopca otoczonego jodłami [Gąsiorowski 1909].

19 Wystarczy przypomnieć, iż ze względu na „paragraf językowy” obchód jubileuszowy został przeniesiony z Poznania do Starołęki [por. Ku czci Stowackiego! 1909; Obchód Juliusza Stowackiego... 1909]. Policja zabroniła młodzieży do lat 18 udziału w obchodzie, przypisując mu charakter wydarzenia politycznego [„Dziennik Poznański” 1909, nr 206]; uroczystości w Starołece odbyły się pod kontrolą policji. W niektórych miejscowościach policja zabroniła urządzania obchodu [„Dziennik Poznański” 1909, nr 206: 3]. Miarą poczucia solidarności narodowej były apele, aby pracodawcy umożliwili pracownikom wzięcie udziału 
odbyły się we Lwowie, w miejscu, gdzie można je było zorganizować w sposób dający dużą swobodę uczestnikom. Tylko takie warunki sprzyjały jednoczesnej realizacji dwóch celów: uczczenia pamięci „swoich bohaterów jako ojców i proroków swoich” oraz postępowania w pracy nad „odrodzeniem” narodu ${ }^{2 \circ}$. „Przymuszeni prawie do szeptania naszą mową” Polacy musieli się imać różnych sposobów, aby poprzez obchody „dać znak łączności duchowej ziem naszych" ${ }^{21}$.

We Lwowie najwcześniej ukonstytuował się Komitet Obchodów Chopina. Od początku przyjął założenie, iż rocznica urodzin artysty musi się zestroić z rocznicą bitwy pod Grunwaldem i nie kolidować z innymi uroczystościami ${ }^{22}$. Przypomnienie zwycięstwa militarnego nad Krzyżakami podnosiło ducha narodu, nadwątlonego przez działania spadkobierców zakonu, którzy konsekwentnie osłabiali żywioł polski na terenie Prus poprzez akcje wywłaszczeniowe [A więc wywłaszczenie! 1910]. Wpisanie artysty w procesy polityczne antagonizujące obie nacje sprawiało kłopoty pojęciowe („Wśród surm opiewających grzmotem wiekopomne zwycięstwo i hymnów błagalnych o zesłanie łask w przyszłości jako

w obchodach [„Dziennik Poznański” 1909, nr 205]. O stosunku władz Rosji do rocznicy Słowackiego wystarczająco wiele mówi notka z Warszawy: „Prezes komitetu prasowego wezwał onegdaj do siebie redaktorów wszystkich pism tutejszych i oświadczył im, iż pismom warszawskim pod groźbą represji nie wolno pisać o jubileuszu Słowackiego” [„Nowa Reforma” 1909]. Oczywiście prasa warszawska informowała o przebiegu obchodów poza państwem rosyjskim. Referowała starannie wystąpienia mówców, wyjaśniających „powody, dla których naród polski czci setną rocznicę urodzin Słowackiego", oraz głosy uzasadniające konieczność sprowadzenia prochów poety na Wawel [„Nowa Gazeta” 1909]. Niemniej „Kurier Warszawski”, który inauguracyjny (pierwszy) numer poświęcił „stuleciu urodzin Juliusza Słowackiego” i zamieścił w nim artykuł Wiktora Hahna Społeczeństwo polskie wobec jubileuszu Stowackiego, a także sprawozdanie z prac komitetu lwowskiego, nie mógł dalej koordynować akcji obchodowej.

20 Wypowiedź Stanisława Gąbińskiego, rektora Uniwersytetu Lwowskiego [por. Akademia ku czci... 1909: 4].

21 Z przemówień Bernarda Chrzanowskiego i Wiktora Hahna podczas uroczystości odsłonięcia pomnika Słowackiego w Poznaniu [„Dziennik Poznański” 1909, $\mathrm{nr} 244]$.

22 W 1910 roku obchodzono sześćsetlecie urodzin Kazimierza Wielkiego, trzystulecie powołania Władysława IV na tron moskiewski, dwieście pięćdziesiątą rocznicę zwycięstwa Stefana Czarneckiego pod Połonnem [por. 1910 1910]. 
gołąb biały nad rozwianymi sztandary unosić się będzie duch wielkiego, bezkrwawego zwycięzcy na polu niepodzielnej dusz ludzkich władczyni, na polu sztuki, duch Fryderyka Szopena" [Obchód Szopenowski we Lwowie 1910]). Te kłopoty rychło pokonano, podkreślając narodowe, rodzime wartości muzyki Chopina (były jednak głosy wykazujące, że redukowanie jego twórczości tylko do sfery narodowej umniejsza jej wszechświatową rangę artystyczną) ${ }^{23}$. Towarzystwo Muzyczne powołało komitet wykonawczy ${ }^{24}$, któremu powierzono przygotowanie programu. $\mathrm{Z}$ ramienia komitetu Mieczysław Soltys udał się do Wiednia, by uzgodnić z Paderewskim program przypadających na październik uroczystości [Stuletnia rocznica obchodów... 1910: 2]. Pianista, będący ich protektorem, a zarazem uczestnikiem, zaakceptował Lwów jako miejsce centralnych obchodów - co przesądziło o ich organizacji w tym mieście. Paderewski był wówczas nie tylko - obok Henryka Sienkiewicza - najbardziej znanym w świecie Polakiem, ale też fundatorem pomnika Władysława Jagiełly w Krakowie, czyli główną osobistością obchodów grunwaldzkich. 15 lipca w Krakowie to właśnie on był bohaterem narodowym, podobnie jak w październiku we Lwowie. Sprawozdania z uroczystości lwowskich podnosiły, że obchody upływały „pod znakiem Chopina i... Paderewskiego” [K.A. 1910] ${ }^{25}$.

Już pierwsze komunikaty lwowskiego komitetu określały datę planowanego obchodu na październik. Rocznicę urodzin świętowano więc $\mathrm{w}$ dniu rocznicy śmierci artysty. Informacje zamieszczone w części prasy warszawskiej i krakowskiej, tłumaczącej

23 („Szum wierzby polskiej jako jedyne źródło natchnienia... to dobre dla Lenartowicza, dla Ignacego Komorowskiego - o wiele za małe dla Moniuszki - cóż dopiero dla tego, którego cały świat jednako rozumie i który całemu światu jest bliski!” [Gomulicki 1910]). Tak zapalczywe podkreślanie narodowych jakości muzyki Chopina odbiło się echem po Europie, wywołując dyskusję o polskim szowinizmie Paderewskiego [zob. Aramis 1911].

24 Komitet liczył 17 członków, przewodniczącym był Aleksander Tchórznicki, zastępcami Adam Krechowiecki i Mieczysław Sołtys [zob. Aw. 1910; Obchód setnej rocznicy... 1910; Setna rocznica urodzin... 1910].

25 W „Dodatku Porannym” [1910] do „Kuriera Warszawskiego” odnotowano: „Bohater chwili, a raczej koryfeusz całej niemal uroczystości szopenowskiej, on, który na tych godach polskiego ducha wycisnął potężne swoje znamię $[\ldots]$ nie schodzi z ust miasta, przedmiotem jest zajęcia ogółu wyłącznym, przytłoczył sobą wszystkich i wszystko!”. 
tę sprzeczność troską organizatorów o należyte wyeksponowanie rocznicy bitwy pod Grunwaldem [Obchód we Lwowie... 1910; Uroczystości Chopina we Lwowie 1910], trzeba traktować z rezerwą, gdyż pojawiły się jednocześnie ze sprawozdaniami z obchodu rocznicy urodzin Chopina, a zatem równolegle z głosami krytyki wobec komitetu lwowskiego. Termin lutowy (okrągła data urodzin) w żaden sposób nie kolidował z datą lipcową, był jednak kłopotliwy logistycznie (podróże w środku zimy, konieczność skupienia uczestników w zamkniętych salach, a zatem ograniczenie liczby i rodzajów imprez oraz ograniczenie liczby publiczności, co wykluczało masowy charakter uroczystości, a przecież celem było właśnie upowszechnienie Chopinowskiej aksjologii). Termin jesienny umożliwiał wykorzystanie przestrzeni otwartych, dawał więcej możliwości urządzania widowisk dla wielotysięcznych tłumów (zresztą obchody grunwaldzkie na prowincji odbywały się też jednocześnie ze zjazdem muzyków [Obchody grunwaldzkie 1910]). O tym, że Lwów umiał przygotować podobne imprezy tak, aby nie zasłaniały rangi uroczystości grunwaldzkich, świadczy fakt, iż lokalne obchody Grunwald zorganizował przed świętem w Krakowie - wydłużyło to okres świętowania i pozwoliło wielu lwowianom, a zwłaszcza gniazdom Sokołów, przybyć na czas do Krakowa. Trzeba przypomnieć, że październikowa data centralnych uroczystości była też w pierwotnych planach komitetu warszawskiego, podobnie jak połączenie obchodu ze zjazdem muzyków polskich. 15 lutego 1910 roku Komitet Obchodu Setnej Rocznicy Urodzin Fryderyka Chopina w Warszawie wydał komunikat:

Dzień 22-gi b.m. otwiera szereg uroczystych obchodów, które trwać będą w Polsce przez cały Rok Jubileuszowy 1910. Komitet przystąpi niezwłocznie do zorganizowania wystawy pamiątek po Chopinie i ogólnomuzycznej. Wystawa ta związana będzie ze zjazdem muzyków polskich, który zbierze się w Warszawie na początku jesieni tegorocznej. W tym samym czasie odbędą się również wielkie koncerty i wielkie święto sztuki polskiej 
zamknie w naszym mieście uroczystości ku czci Chopina ${ }^{26}$. [Obchód szopenowski 1910]

Komitet warszawski zrobił tyle, ile w ówczesnych realiach politycznych było możliwe. Skoro władze rosyjskie utrudniały postawienie pomnika Chopina mimo przeprowadzonego konkursu; skoro przez tyle lat nie dawało się $\mathrm{w}$ Warszawie zorganizować zjazdu uczonych polskich, to szanse na zmianę tego stanu byly iluzoryczne. Warszawscy muzycy i muzykolodzy pojechali do Lwowa. „Czego dokonać nie mogła wielka Warszawa, dokonał o wiele mniejszy Lwów" [Poliński 1910, nr 309]. Na pociechę został postulat zjazdu muzyków, by kolejne spotkanie odbyło się za dwa lata w Warszawie [Poliński 1910, nr 310].

Obchody w formie koncertów, wieczorów muzycznych, odczytów objęły kraj i zagranicę (Odessa, Kijów, Europa Zachodnia, USA). Trwały przez cały rok aż do początków 1911 roku. Wszystkie miasta większe i spora część mniejszych w trzech zaborach urządzily uroczystości ku czci Chopina. Dzienniki warszawskie, łódzkie, wileńskie, poznańskie, krakowskie i lwowskie starały się odnotowywać wysiłki organizacyjne i efekty artystyczne działań tysięcy anonimowych aktywistów lokalnych i wielu stowarzyszeń, choć najpewniej nie dałoby się stworzyć pełnej listy miejscowości oraz osób, którym społeczeństwo zawdzięczało to ożywienie ducha narodowego. Koncentracja uroczystości miała miejsce na przełomie lutego i marca oraz pod koniec października 1910 roku. Tym samym obchody Chopinowskie stały się ramą, w którą wpleciono rocznicę grunwaldzką. Noworoczne numery czasopism mówiły o Grunwaldzie i drukowały Rotę Marii Konopnickiej. Chopinowskie polonezy i mazurki utrwalały poczucie jedności kulturalno-uczuciowej narodu i wpisywały się w ideę solidarnego czynu jego obrony. Z niesmakiem i oburzeniem przyjęto koniunkturalizm polityczny arystokracji (Antoni Wodzicki, Stanisław Tarnowski), która demonstracyjnie odsunęła się od udziału w uroczystości

26 Komunikat został przedrukowany w dziennikach wydawanych w Warszawie i innych miastach Królestwa Polskiego, a także w Cesarstwie [„Kurier Litewski” 1910]. 
grunwaldzkiej, uzasadniając decyzję troską o los Polaków na terenie Prus ${ }^{27}$. Inna rzecz, że gdy na uroczystości Chopinowskiej we Lwowie ten sam Tarnowski wystąpił w „stroju polskim”, co wszak było symbolicznym aktem ideowo-politycznego separowania się od ludu i idei demokratycznej, prasa nie wypominała mu wcześniejszego koniunkturalizmu.

Przypadające na 22 lutego uroczystości przyniosły ogromny plon poznawczo-formacyjny w postaci specjalnych numerów tygodników i dzienników poświęconych Chopinowi. Był bardziej imponujący niż ten z roku 1899. Zwraca uwagę szczególnie efektywna praca redakcji pism codziennych, ponieważ z racji dużych nakładów docierały one do setek tysięcy czytelników. Zauważyć można także jeszcze większy niż podczas obchodów pięćdziesięciolecia zgonu artysty wysyp okolicznościowych wierszy, a także wyjątkowo częste przedrukowywanie wiersza Konopnickiej Na grób Chopina, co wraz z powszechnością Roty w tym roku przyczyniło się do wywołania zbiorowego uczucia żałoby narodowej po śmierci poetki i odprawienia jej pogrzebu we Lwowie niemal w przededniu obchodów Chopinowskich. Poczucie osierocenia i straty kogoś, kto wyrażał nastroje i uczucia wszystkich, przeniosło się znad trumny Konopnickiej na sale koncertowe, w których brzmiały tony Chopina. Trwały dorobek lutowego święta to niewątpliwie odsłonięcie tablicy pamiątkowej na dziedzińcu gmachu Towarzystwa Przyjaciół Nauk w Poznaniu. Odbyło się ono przy minimalnym udziale publiczności, ograniczonej tylko do członków Towarzystwa - policja i tym razem skrupulatnie pilnowała, aby kult artysty nie mógł się rozszerzać [Odsłonięcie tablicy pamiątkowej... 1910].

Dla pogłębienia pamięci o muzyku ważnym dorobkiem komitetu warszawskiego miało być zorganizowanie tzw. wystawy pamiątek na wzór wystawy przygotowanej w roku 1905. Inicjatywa ta doprowadziła do utworzenia w Paryżu Muzeum Chopina [Muzeum Chopina $w$ Paryżu 1911], ale w Warszawie wywołała

27 Przegląd opinii: W sprawie obchodu... [1910], Miscellanea krakowskie [Xyz 1910], Zamachy na obchód grunwaldzki [1910], Z powodu uroczystości... [1910]. Satyry na Antoniego Wodzickiego i Stanisława Tarnowskiego publikowało czasopismo „Mucha” [1910]. 
kompetencyjne spory między komitetem a sekcją chopinowską, choć pozyskano też nowe eksponaty, zaprezentowane m.in. we Lwowie [Dni Chopinowskie 1910; Pamiatki po Chopinie 1910; Warsz. Tow. Muzyczne 1911]. Trwałym śladem jubileuszu miał też być czysto muzyczny plon Roku Chopina. Komitet lwowski ogłosił w maju warunki konkursu na dzieło muzyczne, którego rozstrzygnięcie miało nastąpić podczas uroczystości we Lwowie organizowanych 22-28 października (konkurs obejmował: „dzieło fortepianowe” na dwie ręce, „kompozycję fortepianową” na cztery ręce, „pieśń jednogłosową z towarzyszeniem fortepianu") [Konkurs im. Chopina 1910]. Nagrodę przyznano Karolowi Szymanowskiemu. Wzrost znaczenia muzyki w bieżącym życiu kulturalnym przyczynił się do powstania nowych inicjatyw kulturalno-społecznych - we Lwowie zawiązało się Towarzystwo im. Szopena ${ }^{28}$, w Łodzi powstało Towarzystwo Muzyczne im. Chopina [Towarzystwo Muzyczne imienia... 1910]. Spośród oferowanych przez rynek producencki pamiątek najliczniej były reprezentowane pocztówki i medaliony. Najważniejszym wszakże efektem Roku Chopinowskiego było duchowe zjednoczenie Polaków, przekroczenie granic postawionych przez rządy zaborcze. Na przywitanie gości przybyłych do Lwowa padły słowa: „[...] oto zebraliście się ze wszech stron trójrozdartej Polski, by złożyć hołd czci i pamięci wielkiemu pieśniarzowi ducha polskiego" [Strenger 1910]. Język, którym posługiwano się podczas omawiania tych uroczystości, obfitował w metafory konotujące sensy integracji narodowej („podano sobie ręce, zjednoczono serca" [Rosenzweig 1910]).

Sprawozdania z lwowskich uroczystości zamieszczała cała polska prasa - obszerne i rzeczowe. Dodatkowo upowszechniały one wiedzę o artyście, pogłębiały jego kult i umacniały narodową tożsamość Polaków. Ale nie mogą przesłaniać faktu, że w Roku Chopina i Roku Grunwaldu Polacy nie byli jednością. Krytykowano komitet poznański [Obchód rocznicy Chopina... 1910]. Kraków, który uznał pierwszeństwo galicyjskiego ministra przed narodowym artystą, doczekał się kpin i ostrych krytyk [Dołęga

28 Konkretne wyliczenie celów Towarzystwa oraz składu prezydium można znaleźć $\mathrm{w}$ publikacji Towarzystwo imienia Szopena [1910]. 
1910; Indyk dla ministra... 1910]. Nawet pod adresem Lwowa organizatora najważniejszych uroczystości - kierowano zarzuty:

[...] obchód chopinowski we Lwowie prawie żadnych nie pozostawił śladów po sobie i żadnych nie wydał dodatnich rezultatów. Chyba ujemne. Rozsiał bowiem wiele nieporozumień, żalów, a zamiast zgromadzić wszystkich polskich muzyków bez względu na zabory, stał się dzięki składowi komitetu uroczystością prawie wyłącznie lokalną i w żadnym razie nie chopinowską ${ }^{29}$. [Samson 1910]

Zapomnianym, choć przecież pouczającym kontekstem obchodów była debata o „kwiatku narodowym”, o symbolicznym godle jednoczącym Polaków. Jedni z całą powagą wpatrywali się w kwiaty, aby w nich dojrzeć analogie $\mathrm{z}$ męczeńskim losem narodu. Inni je wyśmiewali [Dybowski 1910: 2; Febris florealis 1910: 2; Kwiat narodowy 1910: 10-11]. Tymczasem dylemat: „polskie czy uniwersalne?” był stałym komponentem mówienia o Chopinie w roku 1910. Zestawienie kontrastujących pojęć: narodowe - ogólnoludzkie, prowadzące do dramatycznych wyborów moralnych, właśnie na uroczystościach we Lwowie zostało przedstawiony tak, że dotarło do wszystkich [Idea ojczyzny 1910; Paderewski 1910]. Kontekstem, o którym nie wolno zapominać, była głośna w świecie, gorsząca sprawa zbrodni w klasztorze jasnogórskim, bo morderca-zakonnik został właśnie wtedy ujęty [Budrewicz 2019b]. Okazało się, że święte dla Polaków miejsce było jaskinią zbójców w habitach. Gniew i upokorzenie narodu obróciły się przeciw klerowi katolickiemu, będącemu dotąd spoiwem narodowej integracji. Dezintegrację międzyzaborową zdołano zahamować, ale pojawiło się widmo dezintegracji ideowej.

29 Oskarżenie w części niesłuszne, gdyż właśnie podczas podobnych zjazdów dbano o to, aby prezydium składało się z reprezentantów wszystkich dzielnic zaborowych [por. Cabaj 2007: 295-296]. 


\section{Bibliografia}

\section{Źródta}

Akademia ku czci Juliusza Stowackiego na Uniwersytecie Lwowskim (1909),

„Gazeta Lwowska”, nr 279, s. 4.

Aramis (1911), O polskość Szopena, „Kurier Warszawski”, nr 190, s. 2-3.

Aw. (1910), Lwów - Chopinowi. Korespondencja własna „Kuriera

Warszawskiego”. Lwów, 8-go stycznia, „Kurier Warszawski”, nr 11, s. 2.

A więc wywtaszczenie! (1910), „Kurier Lwowski”, nr 11, s. 1.

-B- (1880), Ku czci Szopena, „Kurier Warszawski”, nr 51, s. 3.

Czapelski Kazimierz (1899), Notatki z Krakowa, „Iris”, z. 11, s. 521.

Dni Chopinowskie. Zjazd muzyków polskich (1910), „Nowa Gazeta”,

nr 497, s. 2.

Dobrzycki Henryk (1908), Narodowość Chopina. Sprawa sprowadzenia

Jego prochów do kraju, „Bluszcz”, nr 21, s. 238.

„Dodatek Poranny” (1910), do: „Kurier Warszawski”, nr 298, s. 1.

Dołęga Benedykt (1855), Fryderyk Szopen, rozm. przepr. Ludwik Enault, „Gazeta Codzienna”, nr 16o, s. 4.

Dołęga Szczęsny (1910), Minister, burmistrz i Chopin. Historyjka wesota

a tym samym bardzo smutna, „Głos Narodu”, nr 51, s. 2-3.

„Dziennik Poznański” (1909), nr 205, s. 3; nr 206, s. 2; nr 244, s. 1; nr 298, s. 1.

Dzień Szopena (1884), „Kurier Warszawski”, nr 289b, s. 2-3.

Dybowski Benedykt (1910), O kwiat narodowy, „Kurier Lwowski”, nr 201,

s. 2.

„Echo Muzyczne, Teatralne i Artystyczne” (1894), nr 42, s. 503.

Febris florealis (1910), „Czas”, nr 102, s. 2.

„Gazeta Lwowska” (1899), nr 65, s. 4; nr 68, s. 3; nr 72, s. 3; nr 156, s. 4.

Gąsiorowski Wacław (1909), O zwłoki Chopina, „Świat”, nr 51, s. 12-13.

Gomulicki Wiktor (1910), Wielcy ludzie, „Słowo”, nr 7, s. 1.

Grabiec (1899), Kronika krakowska, „Nowa Reforma”, nr 240, s. 1-2.

Halszka z Zaskala (1910), Fryderyk Szopen 1810-1910, „Polak - Katolik”,

nr 42, s. 2.

Hotd Chopinowi (1899), „Dziennik Polski”, nr 300, s. 2.

Idea ojczyzny (1910), „Kurier Litewski”, nr 31, s. 4.

Indyk dla ministra zwyciężyt Chopina (1910), „Głos Narodu”, nr 50, s. 2.

K.A. (1910), Uroczystości Chopinowskie we Lwowie. Lwów, 22 października, „Kurier Poznański”, nr 246, s. 1.

Karasowski Maurycy (1877), Fryderyk Chopin, „Antrakt: Gazeta

Teatralna”, nr 74, s. 1. 
Kleczyński Jan (1880), Ostatnie chwile Chopina, „Echo Muzyczne”, nr 20, s. 159.

Konkurs im. Chopina (1910), „Nowa Gazeta”, nr 248, s. 2.

K.R. (1899), Paryż, 26 października, „Dziennik Polski”, nr 300, s. 1.

Kronika (1880), „Echo Muzyczne”, nr 6, s. 47; nr 11, s. 89.

Kronika (1891), „Czas”, nr 201, s. 2.

Kronika miejscowa i zamiejscowa (1890), „Gazeta Narodowa”, nr 176, s. 3. Kronika tygodniowa (1880), „Tygodnik Ilustrowany”, nr 219, s. 151.

Ku czci Stowackiego! (1909), „Postęp”, nr 205, s. 2.

„Kurier Litewski” (1910), nr 27, s. 3.

„Kurier Warszawski” (1874), nr 48, s. 4.

„Kurier Warszawski” (1894), nr 285, s. 3.

Kwiat narodowy (1910), „Kurier Warszawski”, nr 51, s. 10-11.

Lector (1898), Z prasy polskiej, „Kurier Warszawski”, nr 183, s. 3.

List W. Żeleńskiego (1891), „Czas”, nr 221, s. 2.

Łuszczkiewicz Władysław (1890), Ze świata sztuki, „Czas”, nr 169, s. 1.

(m) (1873), Towarzystwo Muzyczne..., „Kurier Warszawski”, nr 38, s. 1.

Manifestacja pod pomnikiem Chopina (1910), „Nowa Reforma”, nr 85, s. 1.

Manifestacja pod pomnikiem Chopina w Krakowie (1910), „Dodatek

Poranny”, do: „Kurier Warszawski”, nr 55, s. 4.

Młodzież akademicka - Szopenowi (1910), „Głos Narodu”, nr 52, s. 3.

„Mucha” (1910), nr 11, s. 6; nr 30, s. 10.

Muzeum Chopina w Paryżu (1911), „Kurier Warszawski”, nr 169, s. 2.

Na cześć Chopina (1899), „Echo Muzyczne, Teatralne i Artystyczne”, $\mathrm{nr} 42$, s. 500.

Niewiadomski Stanisław (1899), Pół wieku po zgonie Chopina, „Słowo

Polskie", nr 252, s. 3 .

„Nowa Gazeta” (1909), nr 400, s. 4.

Nowa ozdoba Plantacji w Krakowie (1891), „Kurier Lwowski”, nr 246, s. 4.

„Nowa Reforma” (1909), nr 139, s. 2.

Obchody grunwaldzkie (1910), „Kurier Lwowski”, nr 510, s. 2.

Obchód Juliusza Stowackiego w Starołęce (1909), „Postęp”, nr 206, s. 2.

Obchód rocznicy Chopina w Poznaniu (1910), „Słowo”, nr 88, s. 1.

Obchód setnej rocznicy urodzin Chopina (1910), „Kurier Lwowski”, nr 11, s. 2.

Obchód szopenowski (1910), „Dodatek Poranny”, do: „Kurier

Warszawski”, nr 47, s. 1.

Obchód Szopenowski we Lwowie (1910), „Kurier Lwowski”, nr 3, s. 3.

Obchód we Lwowie ku czci Chopina (1910), „Słowo”, nr 485, s. 1.

Odpowiedzi redakcji (1904), „Dodatek Poranny”, do: „Kurier

Warszawski”, nr 55, s. 5.

Odsłonięcie tablicy pamiątkowej Fryderyka Chopina w gmachu Towarzystwa

Przyjaciót Nauk (1910), „Dziennik Poznański”, nr 43, s. 1.

Paderewski a Roosevelt (1910), „Kurier Lwowski”, nr 212, s. 5. 
Paderewski Ignacy (1910), Kilka stów o Chopinie: Odczyt wypowiedziany na obchodzie uroczystym ku czci Chopina we Lwowie dnia 23 października 1910, „Czas”, nr 485, s. 2.

Pamiątki po Chopinie (1910), „Słowo”, nr 112, s. 3.

Pamięci Fryderyka Szopena (1880), „Gazeta Polska”, nr 52, s. 2.

Poliński Aleksander (1894), Dla Chopina, „Kurier Poranny”, nr 286, s. 2.

Poliński Aleksander (1910), Uroczystości szopenowskie we Lwowie, Kurier Warszawski”, nr 309, s. 2; nr 310, s. 3.

-Q- (1873), Wczorajszy wieczór..., „Kurier Warszawski”, nr 41, s. 2.

Rosenzweig Józef (1910), Obchód szopenowski we Lwowie, „Słowo”, nr 491, s. 1 .

Rozmaitości (1881), „Echo Muzyczne”, nr 2, s. 16.

Rzeczy bieżące (1879), „Echo Muzyczne”, nr 9, s. 1; nr 23, s. 3.

Samson (1910), Po obchodzie chopinowskim we Lwowie. Stów kilka

o uroczystości i nowym konkursie, „Przegląd Muzyczny”, nr 23, s. 8.

Sarmaticus (1898), Z prasy polskiej, „Rozwój”, nr 222, s. 3.

Setna rocznica urodzin Chopina (1910), „Gazeta Lwowska”, nr 4, s. 4.

„Słowo Polskie” (1899), nr 44, s. 4; nr 60, s. 3; nr 72, s. 2.

Strenger Henryk (1910), Muzykom polskim na powitanie!, „Kurier

Lwowski”, nr 491, s. 2.

St. (1885), Händel i Bach, „Kurier Warszawski”, nr 58b, s. 2-3.

Stuletnia rocznica obchodów Chopina (1910), „Kurier Lwowski”, nr 31, s. 2. Święto Chopina (1894), „Tygodnik Ilustrowany”, nr 42, s. 250-251.

Teatr i sztuka (1890), „Gazeta Polska”, nr 170, s. 2.

Towarzystwo imienia Szopena (1910), „Kurier Lwowski”, nr 496, s. 2-3.

Towarzystwo Muzyczne imienia Chopina w Łodzi (1910), „Rozwój”, nr 169, s. 1-2.

1910 (1910), „Gazeta Lwowska”, nr 2, s. 4.

Urbanus (1894), Warszawa, 14 października, „Kraj”, nr 40, s. 20-21.

Uroczystości Chopina (1894), „Echo Muzyczne, Teatralne i Artystyczne”, $\mathrm{nr} 42$, s. 501.

Uroczystości Chopina we Lwowie (1910), „Czas”, nr 485, s. 1.

Uroczystość Chopina (1894), „Kurier Warszawski”, nr 285, s. 1-3.

Uroczystość w Żelazowej Woli (1894), „Wędrowiec”, nr 42, s. 823.

Uwagi śledziennika (1891), „Diabeł”, nr 19, s. 2.

Warsz. Tow. Muzyczne (1911), „Nowa Gazeta”, nr 198, s. 5.

Wasz. (1910), Hołd ludu Szopenowi, „Przyjaciel Ludu”, nr 46, s. 9-10.

W setna rocznicę urodzin Szopena (1910), „Dziennik Poznański”, nr 15, s. 5. W sprawie obchodu grunwaldzkiego (1910), „Dodatek Poranny”, do:

„Kurier Warszawski”, nr 77, s. 3-4.

Xyz (1910), Miscellanea krakowskie, „Nowa Gazeta”, nr 125, s. 1.

Z. (1899), Pamiątki po Szopenie, „Tygodnik Ilustrowany”, nr 42, s. 819. Zamachy na obchód grunwaldzki (1910), „Nowa Reforma”, nr 123, s. 1. 
Z Krakowa. 16/1o (1899), „Kurier Poranny”, nr 289, s. 5.

Z powodu uroczystości grunwaldzkiej (1910), „Słowo”, nr 124, s. 3.

Z Warszawy (1899), „Czas”, nr 240, s. 2.

Żeleński Władysław (1899), Fryderyk Chopin w pięćdziesiąta rocznicę zgonu, „Echo Muzyczne, Teatralne i Artystyczne”, nr 41, s. 483.

\section{Literatura}

Bończa-Tomaszewski Nikodem (2006), Źródła narodowości. Powstanie i rozwój polskiej świadomości w II połowie Xx i na początku XX wieku, Wydawnictwo Uniwersytetu Wrocławskiego, Wrocław.

Budrewicz Tadeusz (2004), Program ugody z Rosja w II połowie XX wieku. Nieskuteczna perswazja, w: Teatr wymowy: formy i przemiany retoryki użytkowej, red. Jolanta Sztachelska, Janusz Maciejewski, Elżbieta Dąbrowicz, Wydawnictwo Uniwersytetu w Białymstoku, Białystok, s. 317-336.

Budrewicz Tadeusz, Bukowski Paweł, Stachura-Lupa Renata, red. (2019), Upominki od narodu. Jubileusze, obchody, rocznice pisarzy, Muzeum Marii Konopnickiej w Żarnowcu, Żarnowiec.

Budrewicz Tadeusz (2019a), Czyj grzech, czyja ekspiacja? O komentarzach do zbrodni na Jasnej Górze (1910), w: (Nie)opowiedziane: Polskie doświadczenie wstydu i upokorzenia od czasu rozbiorów do dzisiaj, red. Hanna Gosk, Ewa Paczoska, Michał Kuziak, Universitas, Kraków, s. 201-216.

Budrewicz Tadeusz (2019b), O ruchliwości przestrzennej literatów doby postyczniowej, w: Literatura i kultura lat 6o. XIX wieku między polityka a prywatnością. Dyslokacje, red. Urszula Kowalczuk, Damian Włodzimierz Makuch, Dawid Maria Osiński, Wydawnictwa Uniwersytetu Warszawskiego, Warszawa, s. 88-103.

Budrewicz Tadeusz (2020), Pytam, wiec jestem... (jaki?). Odpowiedzi Redakcji w „Przegladzie Tygodniowym”, w: Pozytywiści warszawscy: „Przegląd Tygodniowy” 1866-1876, red. Anna Janicka, Katedra Badań Filologicznych „Wschód - Zachód”, Zakład Literatury Pozytywizmu i Młodej Polski, Wydział Filologiczny Uniwersytetu w Białymstoku, Białystok, s. 63-78.

Cabaj Jarosław (2007), Walczyć nauką za sprawę Ojczyzny. Zjazdy ponadzaborowe polskich środowisk naukowych i zawodowych jako czynnik integracji narodowej (1869-1914), Wydawnictwo Akademii Podlaskiej, Siedlce.

Gabryś-Sławińska Monika (2015), Jubileusze w „niejubileuszowym” 1911 roku. Przypadek „Tygodnika Ilustrowanego”, „Wiek XIx”, s. 379-394. 
Galos Adam (1976), Tendencje integracyjne i dezintegracyjne na ziemiach polskich $w$ dobie popowstaniowej (do 1914 r.), w: Drogi integracji społeczeństwa w Polsce XIX-XX w., red. Henryk Zieliński, Ossolineum, Wrocław, s. 9-33.

Galos Adam (1993), Obchody rocznicowe na prowincji zaboru austriackiego, w: Studia z dziejów prowincji galicyjskiej, Wydawnictwo Uniwersytetu Wrocławskiego, Wrocław, s. 89-112.

Hahn Wiktor (1916), Bibliografia o Juliuszu Stowackim za rok 1909, wstęp Józef Kallenbach, Lwów.

Jankowska Małgorzata (2014), Literatura a pamięć kulturowa. Obrazoburcze rewitalizacje mitów, „Czytanie Literatury. Łódzkie Studia Literaturoznawcze”, nr 3, s. 133-152.

Marzec Grzegorz (2015), Romantyczne metafory pamięci, „Wiek XIX”, s. $178-196$.

Micińska Magdalena (1997), Gołąb i orzet. Obchody rocznic kościuszkowskich w latach 1894 i 1917, Neriton, Warszawa.

Minta-Tworzowska Danuta (2013), Pamięć, „miejsca pamięci” jako budujące tożsamość $w$ ujęciu archeologicznym, „Przegląd Archeologiczny", vol. 61, s. 33-50.

Napiórkowski Marcin (2013), Uroczystości żatobne jako narzędzie legitymizacji i delegitymizacji władzy, „Pamiętnik Literacki”, z. 4, s. $135-152$.

Piotrowska Magdalena (2011), Narodowe widowiska kulturowe.

Uroczystości żałobne i rocznicowe $w$ Wielkopolsce (1815-1914), Wydawnictwo Naukowe UAM, Poznań.

Piotrowska Magdalena (2018), Wiek XIX w obrazach świetlanych, „Wiek XIX", s. 31-50.

Piotrowska Magdalena (2019), Rocznice narodowe jako medium pamięci kulturowej, „Napis”, s. 249-266.

Rogosz Józef (1876), Artur Grottger - Jan Matejko. Studia o sztuce $w$ Polsce, Redakcja Tygodnia, Lwów.

Stępnik Krzysztof (2012), Setna rocznica urodzin Józefa Ignacego Kraszewskiego w prasie warszawskiej, Wydawnictwo UMCs, Lublin.

Studnicki Władysław (1915), Rocznice dziejowe, „Goniec Wieczorny”, nr 610, s. 1.

Świejkowski Emmanuel (1905), Pamiętnik Towarzystwa Przyjaciół Sztuk Pięknych w Krakowie 1854-1904. Pięćdziesiąt lat działalności dla ojczystej sztuki, Towarzystwo Przyjaciół Sztuk Pięknych w Krakowie, Kraków.

Tabaszewska Justyna (2016), Poetyki pamięci. Wspótczesna poezja wobec tradycji i pamięci, IBL PAN, Warszawa. 
Tarnowski Stanisław (1892), Chopin i Grottger. Dwa szkice, Księgarnia Spółki Wydawniczej Polskiej, Kraków.

Tobiczyk-Stefanowska Władysława, oprac. (1909), W stuletnia rocznicę urodzin Fryderyka Chopina 1810-1910. Wyjątek $z$ „Encyklopedii muzycznej”, Księgarnia Zienkowicza i Chęcińskiego, Lwów.

Wszelaczyński Władysław (1891), Obchody narodowe i muzyka, „Gazeta Narodowa", nr 284, s. 1-2.

Żukowski Otto Mieczysław (1910), Wstęp, w: tegoż, Fryderyk Chopin wświetle poezji polskiej, Księgarnia Zienkowicza i Chęcińskiego, Lwów-Warszawa.

\section{Tadeusz Budrewicz}

\section{Celebration of Chopin's Birthday in 1910 and National Integration. Chopin and the Culture of Memory}

The article presents the events of the celebration of Chopin's 1ooth birthday in 1910. The article is based on the accounts published in the daily press of the time. The growth of Chopin's cult in Polish lands culturally connected the nation divided both politically and administratively between three countries (Austria, Prussia and Russia). Despite disruptions by the police that inhibited the organisation of the celebrations in Poznan and Warsaw, the Polish people treated them as a nation-wide occasion and used that time to integrate. The key events were the 5oth anniversary of Chopin's death (1899) and the 1ooth anniversary of his birthday (1910). The year 1910 was also the 5ooth anniversary of the Battle of Grunwald which saw the Poles defeat the Germans. Chopin's year had immense patriotic meaning and integrated the nation living under foreign rule.

Keywords: Chopin; anniversary; celebration; nation; culture.

Tadeusz Budrewicz - profesor zwyczajny doktor habilitowany, historyk literatury XIX wieku, edytor, biograf. Zajmują go głównie konteksty ideowo-kulturowe literatury. Studiuje dokumenty i źródła dotąd nieeksplorowane w literaturoznawstwie, m.in. prasę codzienną i jej zawartość poetycką. Interesuje się kulturą funebralną i rocznicową. Autor licznych prac o Józefie Ignacym Kraszewskim, Marii Konopnickiej, Elizie Orzeszkowej, Bolesławie Prusie, Henryku Sienkiewiczu, Adamie Asnyku. Najnowsze publikacje książkowe: Pogrzeby pisarzy polskich XIX wieku, Ojcowie pisarze i córki pisarki. 